\title{
Metal Input in Lettuce Grown in Urban Agricultural Soils
}

\author{
Silke Cram¹, Pilar Fernández¹, Horacio Carranza¹, Manuel Hernández², Claudia Ponce de León², \\ Ana M. Noguez Gálvez ${ }^{1}$
}

${ }^{1}$ Instituto de Geografía, Universidad Nacional Autónoma de México, Ciudad Universitaria, Ciudad de México, México ${ }^{2}$ Facultad de Ciencias, Universidad Nacional Autónoma de México, Ciudad Universitaria, Ciudad de México, México Email: silkecram@igg.unam.mx

How to cite this paper: Cram, S., Fernández, P., Carranza, H., Hernández, M., de León, C.P. and Gálvez, A.M.N. (2020) Metal Input in Lettuce Grown in Urban Agricultural Soils. Open Journal of Soil Science, 10, 137-157.

https://doi.org/10.4236/ojss.2020.104007

Received: March 11, 2020

Accepted: April 27, 2020

Published: April 30, 2020

Copyright (c) 2020 by author(s) and Scientific Research Publishing Inc. This work is licensed under the Creative Commons Attribution International License (CC BY 4.0).

http://creativecommons.org/licenses/by/4.0/

\begin{abstract}
Urban agriculture plays an important role in supplying produces to big cities; however, the quality of water used for irrigation can hinder this activity. Hence, the purpose of this study was to evaluate metal inputs, as well as their transfer and translocation factors, in lettuce (Lactuca sativa L.) crops cultivated in an urban plot. The research was conducted during the dry and rainy seasons. In the former, crops were irrigated with treated wastewater, whereas during the latter, crops were maintained just with rainwater. Composite samples for soils and plants were collected from the same plot during two crop cycles in 2013. Some edaphic variables were measured. Total metal concentration was determined, for both, soils and lettuce plants (leaves and roots). Water soluble and exchangeable soil metal fractions were also analyzed. A multivariate analysis of variance was performed to test for differences between seasons, among the variables analyzed. There were significant differences in edaphic characteristics between seasons. However, there was no difference in total metal content, except for Mn. Concentration of soluble metals was lower than exchangeable metal concentration, for both seasons. There was no correlation in total metal concentration between soils and plants. Transfer factor values were higher for $\mathrm{Cd}, \mathrm{Mn}$ and $\mathrm{Zn}$ for the dry season, while for $\mathrm{Cu}, \mathrm{Fe}$ and $\mathrm{Pb}$ were higher during the rainy season, as well as the translocation factors for all metals. Soil characteristics, together with transfer and translocation factors, showed temporal variations, leading to different metal concentrations in the edible lettuce tissues between the two analyzed crop cycles. The incorporation of metals is particular for each site, season and crop management type. Our results indicate that the metal concentration in lettuce tissues places no harm to human health. However, management strategies for urban agriculture must consider specific studies for each site.
\end{abstract}




\section{Keywords}

Transfer Factor, Translocation Factor, Seasonal Variation, Wastewater Irrigation

\section{Introduction}

In order to achieve food security, it is essential to increase food production. Urban agriculture is a resourceful practice that can help to accomplish this necessity, guaranteeing both food quality and quantity [1]. However, different activities that take place in the cities cause environmental alterations and accumulation of waste materials that contaminate soils, water and air. Pollutants may have an adverse effect on crop development, and they may also enter the food chain, via incorporation into the plant, resulting in an important route of exposure for those who consume these produces [2]. These problems have prevented health authorities to approve the consumption of crops that have grown in urban agriculture parcels [3] and those that have been irrigated with wastewater. The use of wastewater in agricultural lands has been practiced for more than 400 years in many parts of the world [4] [5] [6]. Nonetheless, its use over long periods of time can cause the accumulation of metals in soils, and their transfer to plants. [7]. The risk involved in growing crops irrigated with wastewater demand systematic evaluations to make the correct decisions and avoid negative effects on the consumers health [8] [9] [10].

Metal mobility and phytoavailability in soils are influenced by different variables like $\mathrm{pH}$, redox potential, texture, quantity and quality of soil organic matter, mineral composition, temperature and water regime [11]. In general, the magnitude of the mobile metal fraction can be inferred by the characteristics of the soil. Those soils with neutral to slightly basic $\mathrm{pH}$, and with high contents of clay and organic matter, are expected to have low metal mobility/availability, and low incorporation rates into plants [12] [13] [14] [15].

Several studies report the lack of significant correlations between soil characteristics, soil metal content and crop metal concentrations [16] [17] [18] [19] [20]; however, the soil labile fraction (soil solution and exchangeable fractions) correlates with metal absorption [11] [21]. Metal concentration in plants is the result not only of soil characteristics, but also the quality of water used for irrigation and the characteristics of the plants themselves. Plant properties linked to metal absorption include species, root absorption capacity, root selectivity, active and passive transfer processes, ionic interactions, rhizosphere physiology and plant-associated microorganisms [22]. Soil properties vary between seasons [23] and also among soil management treatments [24] [25]. This variability together with the plant characteristics will define the way in which metal transfers and translocation into plants will occur [26]. The complexity and the many variables involved in the metal transfer from soil to plants have to be considered for every 
particular soil-plant system, in order to establish urban agricultural that is hazard free to human health [11].

According to FAO [27] just 19 percent of the urban agriculture areas (Chinampa System) in Mexico City is still in use, this represents 19,213 tons of food, from which 7453 tons correspond to lettuce cultivation, making this crop economically and nutritionally important. The use of treated wastewater for irrigation has undoubted benefits; nevertheless, its pollutants content may have serious long-term implications for food security. In this study we evaluated the variability of metal input in lettuce (Lactuca sativa L.) cultivated in an urban agricultural soil, irrigated with treated wastewater during the dry season, and rainwater through the rainy season. The objectives were: 1) to estimate the variability of some edaphic parameters and metal content in the soil $(\mathrm{Cd}, \mathrm{Cu}, \mathrm{Ni}, \mathrm{Fe}, \mathrm{Mn}$, $\mathrm{Pb}$, and $\mathrm{Zn}$ ), in the dry and rainy seasons; 2) to correlate extractable metal concentrations (total and labile fraction) with metal contents in lettuce tissues ( Lactuca sativa L.) and 3) to estimate transfer and translocation factors in the dry and rainy seasons. The information obtained will be used to design strategic management practices to minimize metal incorporation into crops and reduce the potential risk to human health.

\section{Methods and Materials}

\subsection{Study Area}

Xochimilco is located in a surviving lacustrine area, within the urban Mexico City $\left(19^{\circ} 19^{\prime}-19^{\circ} 09^{\prime} \mathrm{N} ; 98^{\circ} 58^{\prime}-99^{\circ} 10^{\prime} \mathrm{W}\right)$. In this area agriculture is carried out in the traditional way called Chinampa, this is an artificial soil which is constructed by using layers of different materials like: plants, lake sediments and organic fertilizers, among others. These soils, classified as terric Anthrosols, are surrounded by canals creating an entire agroecosystem [28] [29]. The traditional chinampa agriculture has been practiced in the Valley of Mexico since pre-Hispanic times [30]; however, population growth, urbanization and the consequent need for services in the megalopolis have gradually modified the environment, threatening this agricultural system and transforming the surrounding area in such a way that chinampas are now considered as urban agriculture. Moreover, the need for drinking water in Mexico City has led to its extraction from all the Xochimilco springs that once provided clean water to the canals. Since 1959, the canals have been fed with wastewater from the surrounding treatment plants and clandestine downloads of untreated sewage residual water [31], discharging pollutants into the system, including metals [32]. This practice represents a potential risk to human and animal health, mainly through the consumption of crops irrigated with this contaminated water. It has been reported that metal concentrations in soils and vegetal tissues irrigated with water from these canals are greater than the maximum limits allowed by Mexican Secretary of Environment and Natural Resources [33] [34]; nevertheless, Chinampas are considered one of the most productive systems ever created [35]. Currently, vegetables such as lettuce, radishes, beets, onions, turnips and zucchini, as 
well as a great variety of flowers are produced on 200 hectares, representing 10 percent of the acreage of vegetables in Mexico City, and these are sold for consumption in several markets of the city.

The climate in the area is temperate sub-humid with rains in summer and early autumn (600 - 800 millimeters, annual total precipitation), with an average annual temperature of $17^{\circ} \pm 7^{\circ}$ Celsius (drier and warmer, $19^{\circ}$ Celsius, in the dry season; more humid and less warm, $17^{\circ}$ Celsius, in the rainy season) [36] [37].

\subsection{Soil and Plant Sampling and Processing}

To assess the effect of water irrigation quality on the metal concentration in lettuce tissues (Lactuca sativa L.), composite samples were collected independently, for both soil and lettuces. The sampling was carried out in two crop cycles: dry and rainy seasons (March-May and August-October 2013, respectively). Lettuce (Lactuca sativa L.) is grown throughout the year with four harvest dates.

The sampled area was divided into three subplots. In each subplot, ten entire lettuce plants (root and all leaves) and the soil around their roots (approx. 0 - 15 centimeters in depth) were collected to form composite samples, for both soil and plant material. The soil $(n=9)$ was sampled three times during each growing season (every 23 days), whereas lettuce plants $(n=3)$ were sampled only in the adult stage (after 70 days). Samples were collected in an " $X$ " design to ensure representativeness through the plot.

Soil samples were stored in polyethylene bags and lettuce samples were stored in paper bags. Both types of samples were kept in coolers and transported to the laboratory for their analysis. Soil samples were air-dried and sieved through a 2 millimeters mesh, immediately upon arrival at the laboratory. Plant material was washed with tap water to remove soil particles, submerged in an acid wash $(0.1$ $\mathrm{M} \mathrm{HNO}_{3}$ ) for three minutes and then rinsed several times with deionized water, to guarantee the complete removal of all the soil particles on the plant surface. Plants were divided into roots and the entire above-ground portion (hereinafter termed leaves) to form a composite sample per plot, which was then dried at $30^{\circ}$ Celsius. Plants were weighed before and after they had been dried.

Dried soil, leaves and roots were ground independently using an agatha mortar and kept in plastic bags at environmental temperature, until analyzed.

\subsection{Laboratory Analysis}

We used deionized water from a Milli-Q system (Barnstead E-pure D4631, Iowa, USA; 18.0 Mohm per centimeter) in all the analysis. Containers and glassware were soaked overnight in 10 percent (volume per volume) $\mathrm{HNO}_{3}$, then thoroughly washed and rinsed with deionized water before their use. All chemicals were analytical grade. The quality of the analytical data was monitored by using duplicates, spikes, blanks, reference materials and certified standards.

\subsubsection{Edaphic Parameters}

Soil $\mathrm{pH}$ was measured in a soil suspension (1:2.5 weight per volume, soil: water) 
with an HI8314 pH meter (Hanna Instruments, Woonsocket, RI, USA) (Method NOM-021-RECNAT-2000, [38]) using J.T. Baker buffer solutions. Electric conductivity (EC) was measured in an extract obtained from a saturated soil-paste (soil: water) [39], using a conductivity meter (HI991301, Hanna Instruments, Woonsocket, RI, USA) and HI6031 calibration solution (Hanna Inst.). Texture was determined by the Bouyoucos hydrometer method [40] and bulk density by the method described by Blake and Hartge (1986) [41]. Organic carbon (Corg.) and total nitrogen $(\mathrm{Nt})$ were quantified with an elemental analyzer (Perkin Elmer 2400 Series II CHNS/O); dissolved organic carbon was measured (DOC) using an Apollo 9000 Combustion TOC Analyzer (Tekmar-Dohrmann, USA). Cation exchange capacity (CEC) was determined by ammonium acetate method $\left(\mathrm{CH}_{3} \mathrm{COONH}_{4} 1 \mathrm{~N} \mathrm{pH} \mathrm{7)}\right.$ (J.T. Baker); Ca and $\mathrm{Mg}$ concentrations were obtained by flame atomic absorption spectrophotometer (PerkinElmer Analyst 800, Perkin Elmer Instruments, Shelton, CT USA); and Na and $\mathrm{K}$ values by flame photometer (Jenway, PFP7, Essex, England). Soluble cations $\left(\mathrm{Na}^{+}, \mathrm{K}^{+}, \mathrm{Ca}^{2+}, \mathrm{Mg}^{2+}\right.$, $\left.\mathrm{NH}_{4}^{+}\right)$and anions $\left(\mathrm{Cl}^{-}, \mathrm{SO}_{4}^{2-}, \mathrm{NO}_{3}^{-}\right.$, and $\left.\mathrm{HCO}_{3}^{-}\right)$were measured in an extract from a saturated soil-paste (soil: water) using liquid chromatography (Waters, Mod. 1525, Milford, MA, USA) with an electrical conductivity detector (Waters, Mod. 432. Milford, MA, USA); for quantifying cations we used a Metrosep C6 column $(250 \times 4.0$ millimeters; Metrohm. Herisau, Switzerland), as for anions we employed an IC-PaK column (4.6 × 75 millimeters; Waters, Milford, MA, USA) and cations with a Metrosep C6 column $(250 \times 4.0$ millimeters; Metrohm). For quality control an internal reference material Xico (Geology Institute, UNAM) was used.

\subsubsection{Soil and Plant Metal Analysis}

In all determinations we used deionized water from a Milli-Q system (Barnstead E-pure D4631, Iowa, USA; 18.0 Mohm per centimeter). Containers and glassware were soaked overnight in 10 percent (volume per volume) $\mathrm{HNO}_{3}$, then thoroughly washed and rinsed with deionized water before use. All chemicals were analytical grade. The quality of the analytical data was monitored using duplicates, spikes, blanks, reference materials and certified standards.

To obtain total metal values for soil and lettuce (leaves and roots), samples were ground using an agatha mortar, until they were fine enough to pass through a 400 sieve, then samples were digested using a microwave digester CEM MARS-5 (CEM corporation Matthews, NC), according to the US-EPA method 3052 (1996) [42]. To measure water-soluble and exchangeable metal fractions in soils, extracts were obtained with deionized water and $0.1 \mathrm{M} \mathrm{NaNO}_{3}$ solution, respectively. Metals were measured by flame $(\mathrm{Cu}, \mathrm{Cr}, \mathrm{Fe}, \mathrm{Mn}, \mathrm{Zn})$ and graphite furnace (Cd) atomic absorption spectrometer (PerkinElmer Analyst 800, Perkin Elmer Instruments, Shelton, CT USA). Metal concentrations in soils and plant extracts were calculated on dry weight basis. The standards used for metal recovery in soils were: SRM 2709 San Joaquin Soil SRM 1570a, and for vegetables, Trace Elements in Spinach Leaves (U.S. National Institute of Standards and Technolo- 
gy)

\subsection{Data Processing}

Free ion activity was obtained from the Windermere Humic Aqueous Model (WHAM). This was used to simulate metals chemical equilibrium in soils dominated by natural organic matter [43]. Interactions between metals and organic matter are simulated as a combination of chemical and electrostatic interactions (Software WHAM 7).

Metal concentrations in soils, roots and leaves were obtained considering the dilution factor and the dry weight of the sample. In order to find the metal concentration of the whole plant (leaves and roots) we used the lettuces total biomass. Metal movement from soil to plant was estimated using two factors: a) transfer factor (soil/plant); and b) translocation factor (root/leaves).

1) Transfer factor $(\operatorname{TrF})$ was calculated as (Equation (1)):

$$
\operatorname{TrF}=\mathrm{VC} / \mathrm{SC}
$$

where $\mathrm{VC}$ is the concentration of the metal in the plant, and SC is the mean total concentration of the metal in soil [26] [44].

2) $\operatorname{Tr}$ Tanslocation factor (TIF) was calculated as (Equation (2)):

$$
\mathrm{TlF}=\mathrm{ALC} / \mathrm{RC}
$$

where ALC is the metal concentration in the aerial part of the plants (leaves) and $\mathrm{RC}$ is the mean concentration in the root [45] [46].

Statistical analyses were performed with Statistica 10.0 for Windows. Prior to the analysis, data were checked for homogeneity of variance by Levene's test and for normal distribution by Kolmogorov-Smirnov test [47]. Comparisons between seasons (dry and rainy) for all soil parameters measured, for soil and plant metal concentrations and between plant organs (root and leaves) were determined by Student's $t$ tests, $U$ de Mann-Whitney test (T). A multivariate analysis of variance (MANOVA) was used to determine whether there were significant differences between dry and rainy seasons among the variables analyzed. Metal concentration and other edaphic variables were expressed as the mean value \pm confidence interval (95\%).

\section{Results and Discussion}

We found, in the soils studied, high contents of Corg (9 - 13 percent) and clay (20 percent) and almost neutral $\mathrm{pH}$ values $(6.8-7.7)$. These results suggest a low mobility and a high binding strength of metals on the soil, in addition to a low incorporation into crops [12] [13]. It can be assumed that chinampa soils possess a good buffering capacity. However, changing conditions in water temperature, quantity and quality, during the year, may induce temporary changes in some soil characteristics, increasing soil metal availability, therefore, the amount that can be absorbed by plants. Moreover, lettuce properties can also exert an influence on metal concentration in their tissues. 


\subsection{Edaphic Parameters}

We found significant differences between seasons for all the parameters measured but Corg, Ntotal and $\mathrm{NO}_{3}$. Values for the dry season samples were higher than those for the rainy season, with exception of CEC which presented lower values (Table 1).

Seasonal variation of some soil physical, chemical and biological characteristics has been previously reported [23] [25] [48] [49]. In this study the differences in soil humidity and temperature, caused by the distinctly dry and rainy seasons, generated variation in the properties and dynamics of the chinampa soils. The poor quality of the water used for irrigation, together with the elevated soil evaporation rates, during the dry months, led to the accumulation of salts in the topsoil [50] [51], as reflected in the higher values of EC, ESP, $\mathrm{Na}$ and $\mathrm{pH}$ for this season.

We found high DOC concentration values, for both dry and rainy seasons (178.7 and 128.5 milligrams per liter, respectively), these figures can be compared to those reported for forest soils (5 - 440 milligrams per liter) [52] [53]; however, data for agricultural soils lie within a range of $0-70$ milligrams per liter, less than half the values found in the chinampa soils. The high amount of

Table 1. Soil characteristics of measured variables in the dry and the rainy season (2013) in the Xochimilco chinampa, Mexico (mean values, $\mathrm{n}=9$ ).

\begin{tabular}{|c|c|c|c|c|}
\hline \multirow{2}{*}{$\begin{array}{c}\text { Variable } \\
\mathrm{pH} \mathrm{H} \mathrm{H}_{2} \mathrm{O}(1: 2.5)\end{array}$} & \multicolumn{2}{|c|}{ Dry season } & \multicolumn{2}{|c|}{ Rainy season } \\
\hline & $7.39^{*}$ & $(0.14)$ & $6.95^{\star}$ & $(0.06)$ \\
\hline DOC Dissolved Corg $\left(\mathrm{mg} \cdot \mathrm{L}^{-1}\right)^{*}$ & $178.70^{*}$ & $(15.16)$ & $128.54^{*}$ & $(7.33)$ \\
\hline Corg $(\%)$ & 12.21 & $(0.72)$ & 11.36 & $(0.58)$ \\
\hline Ntotal (\%) & 0.90 & $(0.07)$ & 0.82 & $(0.04)$ \\
\hline Exchangeable cations $\left(\mathrm{Cmol}(+) \mathrm{kg}^{-1}\right)$ & $75.74^{*}$ & $(2.29)$ & $64.70^{\star}$ & $(1.47)$ \\
\hline $\operatorname{CEC~}\left(\mathrm{cmol}(+) \mathrm{kg}^{-1}\right)$ & $52.04^{*}$ & $(1.44)$ & $59.30^{*}$ & $(1.28)$ \\
\hline ESP (\%) & $2.56^{*}$ & $(0.25)$ & $0.89^{*}$ & $(0.07)$ \\
\hline $\mathrm{EC}\left(\mathrm{dS} \mathrm{cm} \mathrm{cm}^{-1}\right)$ & $1.50^{*}$ & $(0.15)$ & $0.56^{*}$ & $(0.07)$ \\
\hline $\mathrm{Na}^{+}\left(\mathrm{cmol}(+) \mathrm{kg}^{-1}\right)$ & $8.90^{*}$ & $(0.83)$ & $1.59^{*}$ & $(0.62)$ \\
\hline $\mathrm{NH}_{4}^{+}\left(\mathrm{cmol}(+) \mathrm{kg}^{-1}\right)$ & $1.22^{*}$ & $(0.14)$ & $0.91^{*}$ & $(0.18)$ \\
\hline $\mathrm{K}^{+}\left(\mathrm{cmol}(+) \mathrm{kg}^{-1}\right)$ & $3.19^{*}$ & $(0.41)$ & $1.43^{*}$ & $(0.34)$ \\
\hline $\mathrm{Ca}^{2+}\left(\mathrm{cmol}(+) \mathrm{kg}^{-1}\right)$ & $12.40^{*}$ & $(1.86)$ & $4.89^{*}$ & $(1.01)$ \\
\hline $\mathrm{Mg}^{2+}\left(\operatorname{cmol}(+) \mathrm{kg}^{-1}\right)$ & $15.38^{*}$ & $(2.54)$ & $4.93^{*}$ & $(1.25)$ \\
\hline $\mathrm{Cl}^{-}\left(\mathrm{cmol}(+) \mathrm{kg}^{-1}\right)$ & $6.25^{*}$ & $(0.90)$ & $0.91^{*}$ & $(0.43)$ \\
\hline $\mathrm{NO}_{3}^{-}\left(\mathrm{cmol}(+) \mathrm{kg}^{-1}\right)$ & 0.22 & $(0.07)$ & 0.66 & $(0.90)$ \\
\hline $\mathrm{SO}_{4}^{2-} \quad\left(\mathrm{cmol}(+) \mathrm{kg}^{-1}\right)$ & $35.16^{*}$ & $(5.24)$ & $10.70^{*}$ & $(2.52)$ \\
\hline $\mathrm{HCO}_{3}^{-}\left(\mathrm{cmol}(+) \mathrm{kg}^{-1}\right)$ & $2.05^{*}$ & $(0.28)$ & $1.30^{*}$ & $(0.15)$ \\
\hline
\end{tabular}

Values in parenthesis: confidence interval $(95 \%) .{ }^{*}$ significant difference $(\mathrm{p}<0.05$, ) between seasons. Bold: higher values. 
DOC found in this research can be explained by the large volumes of compost and manure continuously applied to chinampa soils [54]. Moreover, the use of treated wastewater for irrigation during the dry season has also an important impact on these soils, by increasing DOC concentration, either by acting as a source of dissolved organic matter (DOM) or by enhancing the solubilization of soil organic matter via an increase in $\mathrm{pH}$ [55]. In soils studied in the Hidalgo State in Mexico, it was found that DOC was derived mainly from the wastewater used for irrigation [56]. In addition, Xiao and Zheng (2000) [57] reported that a rise in temperature results in an increase of microbial activity, boosting DOC concentrations. Irrigation with wastewater from the canals and the higher temperatures (by an average of $2^{\circ}$ Celsius) in dry conditions, may explain the significantly higher DOC concentrations during the dry season in the present study.

Besides the influence of the seasonal variability on metal availability, crop management is also an important aspect that needs to be considered during the design of sampling strategies when soil properties are compared in time or with findings from other studies, in order to distinguish seasonal variation from long-term change.

\subsection{Metals in Soil}

There were no significant differences in soil total metal concentration between seasons, except for $\mathrm{Mn}$, which presented higher values in the rainy season samples (Table 2). Metal concentrations in soils decreased in the following order: $\mathrm{Fe}>\mathrm{Mn}>\mathrm{Zn}>\mathrm{Cr}>\mathrm{Cu}>\mathrm{Pb}>\mathrm{Cd}$. None of the metals measured exceeded the background levels reported in the literature or the Canadian Soil Quality Guidelines (2007) [58] (Table 2), even when the concentration of metals in the surface horizon was between 50 to 100 percent greater than in the deeper horizons of these soils (data not shown) [59]. This suggests an input to the soils, which may come from soil amendments [60], irrigation water [61] [62] and atmospheric deposition [63].

Regarding bioavailable metals, there were no significant differences between dry and rainy seasons for Cd concentrations in any of the evaluated forms; however, values for the other measured metals were significantly higher for the rainy season than those in the dry season (Table 3). In the case of Pb, the soluble fraction was not significantly different between seasons. The differences in concentration between the two seasons were, in general, greater by an order of magnitude.

Concentration of the bioavailable forms (soluble + interchangeable) in the dry season varied in the following way: $\mathrm{Cd}<\mathrm{Cr}=\mathrm{Cu}<\mathrm{Pb}<\mathrm{Zn}<\mathrm{Fe}<\mathrm{Mn}$ and in the rainy season $\mathrm{Cd}<\mathrm{Cr}>\mathrm{Pb}<\mathrm{Cu}<\mathrm{Zn}<\mathrm{Mn}<\mathrm{Fe}$. This bioavailable fraction represents 0.1 to 10 percent of the total metal concentration in the soil (Table 3).

Contrary to what was anticipated, DOC does not determine a higher solubility of metals for the soils studied. We found no significant relationship between DOC and available metals. There are contradictory results regarding the influence 
Table 2. Metal concentrations in chinampa soils in the dry and rainy seasons (mean values, $\mathrm{n}=9$ ).

\begin{tabular}{|c|c|c|c|c|c|c|}
\hline \multirow{2}{*}{$\begin{array}{c}\text { Metal } \\
\mathrm{Cd}\end{array}$} & \multicolumn{2}{|c|}{$\begin{array}{c}\text { Dry Season } \\
\left(\mathrm{mg} \cdot \mathrm{kg}^{-1}\right)\end{array}$} & \multicolumn{2}{|c|}{$\begin{array}{l}\text { Rainy season } \\
\left(\mathrm{mg} \cdot \mathrm{kg}^{-1}\right)\end{array}$} & \multirow{2}{*}{$\begin{array}{c}\begin{array}{c}\text { Baseline soil } \\
\text { concentration }^{\dagger} \\
\left(\mathrm{mg} \cdot \mathrm{kg}^{-1}\right)\end{array} \\
0.05-1.0\end{array}$} & \multirow{2}{*}{$\begin{array}{c}\begin{array}{c}\text { Soil Quality } \\
\text { Guidelines } \\
\text { (mg.kg }\end{array} \\
1.4\end{array}$} \\
\hline & 0.36 & $(0.03)$ & 0.36 & $(0.02)$ & & \\
\hline $\mathrm{Cr}$ & 48.9 & (1.6) & 50.6 & $(0.9)$ & $10-50$ & 64 \\
\hline $\mathrm{Cu}$ & 31.5 & $(1.2)$ & 31.7 & $(1.2)$ & $10-40$ & 63 \\
\hline $\mathrm{Pb}$ & 21.8 & $(3.4)$ & 22.7 & (3.5) & $10-30$ & 70 \\
\hline $\mathrm{Zn}$ & 98 & (13) & 95 & $(12)$ & $20-200$ & 200 \\
\hline $\mathrm{Fe}$ & 11,313 & (299) & 11204 & $(86)$ & $1 \%-5 \% \S$ & - \\
\hline $\mathrm{Mn}^{*}$ & 384 & (25) & 443 & (25) & $0.03 \%-1 \%{ }^{\text {䟩 }}$ & - \\
\hline
\end{tabular}

Values in parenthesis: confidence interval $(95 \%)$; significant difference $(\mathrm{p}<0.05)$ between seasons. Bold: higher values. [64] ${ }^{\dagger, \ddagger}$ Canadian Soil Quality Guidelines (2007) [58]. -, not reported. $\$ \mathrm{Fe}_{2} \mathrm{O}_{3},{ }^{\ddagger \ddagger} \mathrm{MnO}$. Fe and Mn values are expressed as percentage.

Table 3. Mean concentrations of bioavailable metals in soil (soluble, interchangeable and the sum of both fractions) in the dry and rainy season, 2013, and their percentage in relation to the total metal concentration.

\begin{tabular}{|c|c|c|c|c|c|c|c|}
\hline \multirow{3}{*}{$\begin{array}{c}\text { Metal } \\
\mathrm{Cd}\end{array}$} & \multirow{3}{*}{$\begin{array}{c}\text { Season } \\
\text { Soil fraction } \\
\text { Soluble }\end{array}$} & \multirow{2}{*}{\multicolumn{2}{|c|}{$\frac{\text { Dry }}{\left(\mathrm{mg} \cdot \mathrm{kg}^{-1}\right)}$}} & \multirow{3}{*}{$\begin{array}{c}\begin{array}{c}\% \text { total } \\
\text { concentration }\end{array} \\
0.96\end{array}$} & \multirow{2}{*}{\multicolumn{2}{|c|}{$\frac{\text { Rainy }}{\left(\mathrm{mg} \cdot \mathrm{kg}^{-1}\right)}$}} & \multirow{3}{*}{$\begin{array}{c}\begin{array}{c}\% \text { total } \\
\text { concentration }\end{array} \\
1.08\end{array}$} \\
\hline & & & & & & & \\
\hline & & \multirow{2}{*}{$\begin{array}{l}0.003 \\
0.013\end{array}$} & \multirow{2}{*}{$\begin{array}{l}(0.001) \\
(0.001)\end{array}$} & & \multirow{2}{*}{$\begin{array}{l}0.004 \\
0.014\end{array}$} & \multirow{2}{*}{$\begin{array}{l}(0.0004) \\
(0.001)\end{array}$} & \\
\hline & Exchangeable & & & 3.52 & & & 3,95 \\
\hline & Sol + Exch & 0.016 & $(0.002)$ & 4.48 & 0.018 & $(0.01)$ & 5.03 \\
\hline \multirow[t]{3}{*}{$\mathrm{Cr}$} & Soluble & $0.01^{*}$ & $(0.002)$ & 0,02 & $0.030^{*}$ & $(0.007)$ & 0.06 \\
\hline & Exchangeable & $0.03^{*}$ & $(0.003)$ & 0.05 & $0.04^{*}$ & $(0.003)$ & 0.09 \\
\hline & Sol + Exch & $0.04^{*}$ & $(0.005)$ & 0.08 & $0.07^{\star}$ & $(0.006)$ & 0.15 \\
\hline \multirow[t]{3}{*}{$\mathrm{Cu}$} & Soluble & $0.012^{*}$ & $(0.002)$ & 0.04 & $0.114^{\star}$ & $(0.007)$ & 0.36 \\
\hline & Exchangeable & $0.026^{*}$ & $(0.001)$ & 0.08 & $0.211^{\star}$ & $(0.01)$ & 0.67 \\
\hline & Sol + Exch & $0.038^{*}$ & $(0.003)$ & 0.12 & $0.326^{\star}$ & $(0.02)$ & 1.03 \\
\hline \multirow[t]{3}{*}{$\mathrm{Pb}$} & Soluble & 0.03 & $(0.004)$ & 0.12 & 0.03 & $(0.003)$ & 0.14 \\
\hline & Exchangeable & $0.09^{*}$ & $(0.01)$ & 0.40 & $0.10^{*}$ & $(0.01)$ & 0.45 \\
\hline & Sol + Exch & $0.11^{*}$ & $(0.01)$ & 0.52 & $0.13^{*}$ & $(0.01)$ & 0.58 \\
\hline \multirow[t]{3}{*}{$\mathrm{Zn}$} & Soluble & $0.58^{*}$ & $(0.08)$ & 0.59 & $1.28^{*}$ & $(0.20)$ & 1.34 \\
\hline & Exchangeable & $1.40^{*}$ & $(0.13)$ & 1.43 & $2.16^{*}$ & $(0.27)$ & 2.28 \\
\hline & Sol + Exch & $1.98^{*}$ & $(0.19)$ & 2.02 & $3.44^{*}$ & $(0.45)$ & 3.63 \\
\hline \multirow[t]{3}{*}{$\mathrm{Fe}$} & Soluble & $4.75^{*}$ & $(1.78)$ & 0.04 & $14.26^{\star}$ & $(1.25)$ & 0.13 \\
\hline & Exchangeable & $8.96^{*}$ & $(1.07)$ & 0.08 & $37.21^{\star}$ & (3.79) & 0.33 \\
\hline & Sol + Exch & $13.71^{*}$ & $(2.81)$ & 0.12 & $51.47^{\star}$ & $(4.21)$ & 0.46 \\
\hline \multirow[t]{3}{*}{$\mathrm{Mn}$} & Soluble & $1.28^{*}$ & $(0.16)$ & 0.33 & $2.17^{\star}$ & $(0.35)$ & 0.49 \\
\hline & Exchangeable & $15.64^{*}$ & $(1.54)$ & 4.08 & $43.27^{\star}$ & $(3.11)$ & 9.77 \\
\hline & Sol + Exch & $16.92^{*}$ & $(1.62)$ & 4.41 & $45.44^{\star}$ & (3.43) & 10.26 \\
\hline
\end{tabular}

Values in parenthesis: confidence interval $(95 \%) .^{*}$ : significant differences $(\mathrm{p}<0.05)$ between seasons. Bold: the season with the higher metal concentration. 
of DOC on soil metal availability. Several authors report that DOC can favor metal solubility in soils [65] [66]. Others relate changes in metal solubility to a high percentage of DOC consisting of humic and fulvic acids, which can form complexes with metal ions and alter the solubility of both the ligand and the bound species [67]. Apparently, the slightly low $\mathrm{pH}$ values and the low salinity conditions (referred to as concentrations of exchangeable bases and soluble cations and anions) in our soils led to greater solubility of metals during the rainy season. The concentration of each metal (total true solution) was also higher in the rainy season ( $\mathrm{p}<0.05$, except for cadmium) (Figure 1 ). The true solution contains all the free ions and simple ligand complexes.
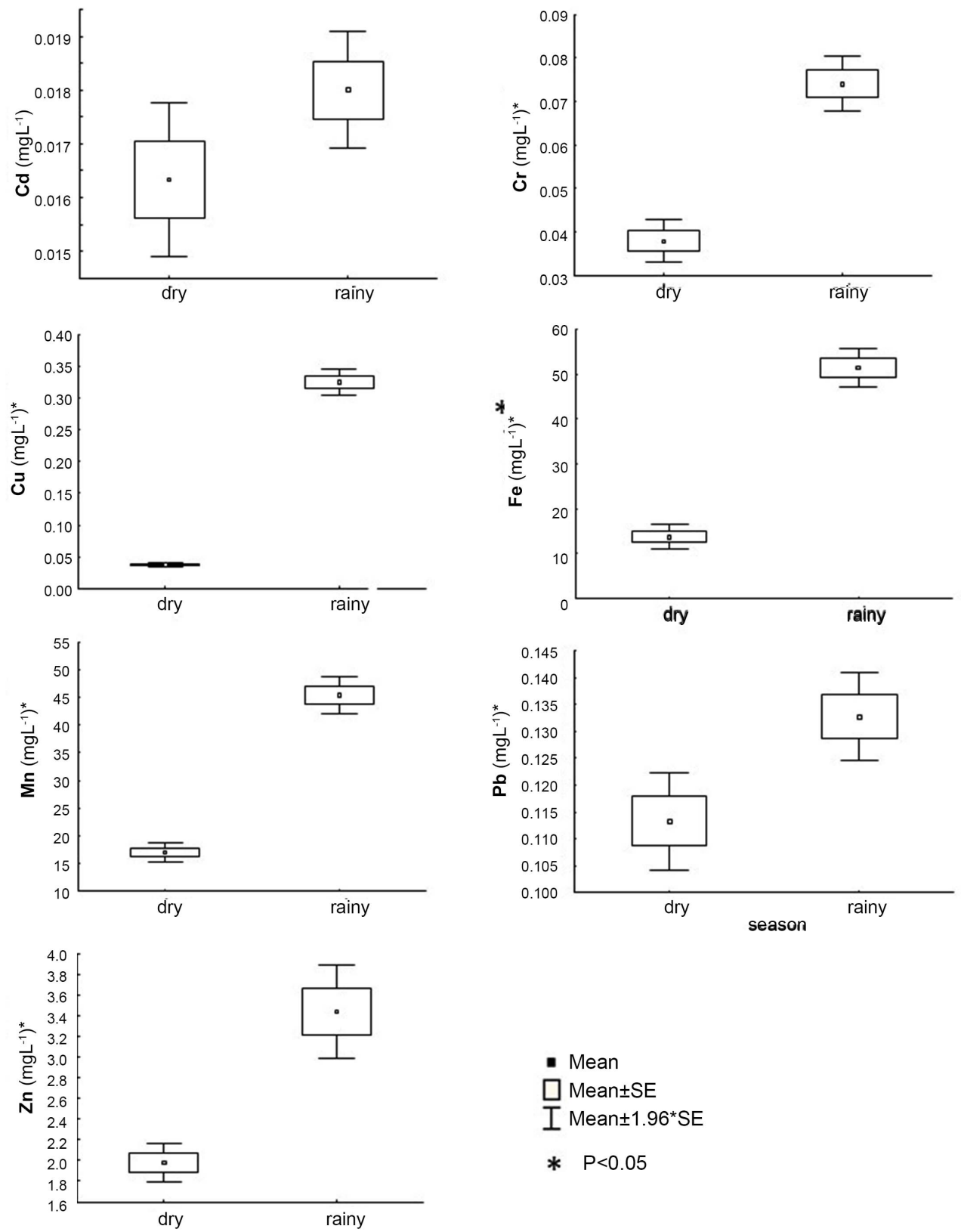

Figure 1. Concentrations by season of available metals (true solution) in the chinampa soils $(\mathrm{n}=9)$. 


\subsection{Metals in Plants}

The metal contents in plants differed significantly between the two seasons. The total concentration in the entire plant (leaves and roots) was higher in the dry season for $\mathrm{Cd}, \mathrm{Mn}$ and $\mathrm{Zn}$; conversely, during the rainy season $\mathrm{Cu}, \mathrm{Fe}$ and $\mathrm{Pb}$ concentrations were higher than in the dry season. Chromium showed no difference between seasons (Table 4).

Concentrations of $\mathrm{Cr}, \mathrm{Cu}, \mathrm{Fe}$ and $\mathrm{Pb}$, for the leaves alone, were higher in the rainy season, whereas $\mathrm{Cd}$ content was higher in the dry season. Contents of $\mathrm{Cd}$, $\mathrm{Fe}, \mathrm{Mn}$ and $\mathrm{Pb}$ in lettuce roots were higher in the dry season, but those of $\mathrm{Cr}, \mathrm{Cu}$ and $\mathrm{Zn}$ did not differ between the two seasons (Table 4 and Figure 2).

Table 4. Metal concentration in lettuce (Lactuca sativa L.) in the dry and rainy seasons of 2013.

\begin{tabular}{|c|c|c|c|c|c|c|c|}
\hline \multirow{4}{*}{$\begin{array}{l}\text { Metal } \\
\text { Cd }\end{array}$} & \multirow{4}{*}{$\begin{array}{l}\text { Plant } \\
\text { tissue } \\
\text { Leaf }\end{array}$} & \multicolumn{4}{|c|}{ Metal $\left(\mathrm{mg} \cdot \mathrm{kg}^{-1}\right)$} & \multirow{2}{*}{\multicolumn{2}{|c|}{$\begin{array}{l}\text { Significant difference in metal } \\
\text { content between leaf and root. }\end{array}$}} \\
\hline & & \multirow{2}{*}{\multicolumn{2}{|c|}{$\begin{array}{c}\text { Dry season } \\
\mathrm{mg} \mathrm{kg}^{-1}\end{array}$}} & \multirow{2}{*}{\multicolumn{2}{|c|}{$\frac{\text { Rainy season }}{\mathrm{mg} \mathrm{kg}^{-1}}$}} & & \\
\hline & & & & & & \multirow[t]{2}{*}{ Dry season } & \multirow[t]{2}{*}{ Rainy season } \\
\hline & & $0.17^{\star}$ & $(0.01)$ & $0.06^{*}$ & $(0.00)$ & & \\
\hline & Root & $0.31^{\star}$ & $(0.04)$ & $0.09^{*}$ & $(0.01)$ & $\mathrm{p}<0.05$ & $\mathrm{p}<0.05$ \\
\hline & Leaf \& Root & $0.19^{\star}$ & $(0.01)$ & $0.06^{*}$ & $(0.00)$ & & \\
\hline \multirow[t]{3}{*}{$\mathrm{Cr}$} & Leaf & $0.07^{\star}$ & $(0.02)$ & $0.17^{\star}$ & $(0.06)$ & & \\
\hline & Root & 0.41 & $(0.15)$ & 0.21 & $(0.15)$ & $\mathrm{p}<0.05$ & - \\
\hline & Leaf \& Root & 0.11 & $(0.04)$ & 0.18 & $(0.07)$ & & \\
\hline \multirow[t]{3}{*}{$\mathrm{Cu}$} & Leaf & $8.52^{*}$ & $(0.72)$ & $12.55^{*}$ & $(0.29)$ & & \\
\hline & Root & 13.49 & $(1.29)$ & 13.41 & $(1.48)$ & $\mathrm{p}<0.05$ & - \\
\hline & Leaf \& Root & $9.17^{*}$ & $(0.71)$ & $12.66^{*}$ & $(0.07)$ & & \\
\hline \multirow[t]{3}{*}{$\mathrm{Fe}$} & Leaf & $139.11^{*}$ & $(10.34)$ & $466.1^{*}$ & $(30.7)$ & & \\
\hline & Root & $659.43^{*}$ & $(63.47)$ & $447.9^{*}$ & $(3.9)$ & $\mathrm{p}<0.05$ & - \\
\hline & Leaf \& Root & $207.26^{*}$ & (15.45) & $463.7^{\star}$ & $(27.1)$ & & \\
\hline \multirow[t]{3}{*}{$\mathrm{Mn}$} & Leaf & 18.73 & $(1.26)$ & 17.96 & $(1.10)$ & & \\
\hline & Root & $33.93^{*}$ & $(1.71)$ & $22.59^{*}$ & $(2.15)$ & $\mathrm{p}<0.05$ & $\mathrm{p}<0.05$ \\
\hline & Leaf \& Root & $20.72^{\star}$ & $(0.90)$ & $18.57^{\star}$ & $(0.71)$ & & \\
\hline \multirow[t]{3}{*}{$\mathrm{Pb}$} & Leaf & $0.14^{*}$ & $(0.02)$ & $0.59^{*}$ & $(0.04)$ & & \\
\hline & Root & $1.20^{*}$ & $(0.08)$ & $0.53^{*}$ & $(0.16)$ & $\mathrm{p}<0.05$ & - \\
\hline & Leaf \& Root & $0.28^{*}$ & $(0.02)$ & $0.58^{*}$ & $(0.06)$ & & \\
\hline \multirow[t]{3}{*}{$\mathrm{Zn}$} & Leaf & 67.61 & $(3.65)$ & 37.72 & (17.68) & & \\
\hline & Root & 90.58 & (13.72) & 69.43 & $(32.88)$ & $\mathrm{p}<0.05$ & - \\
\hline & Leaf \& Root & $70.62^{\star}$ & $(4.91)$ & $41.90^{*}$ & $(17.25)$ & & \\
\hline
\end{tabular}

In parenthesis, confidence interval $(95 \%)$; ${ }^{*}$ : significant difference $(\mathrm{p}<0.05)$ between seasons; Bold: the season with the higher metal concentration; -: $p>0.05$. Leaves and Roots concentrations were estimated by considering total biomass (leaves and roots) and the mean concentrations of metals obtained from each organ. 

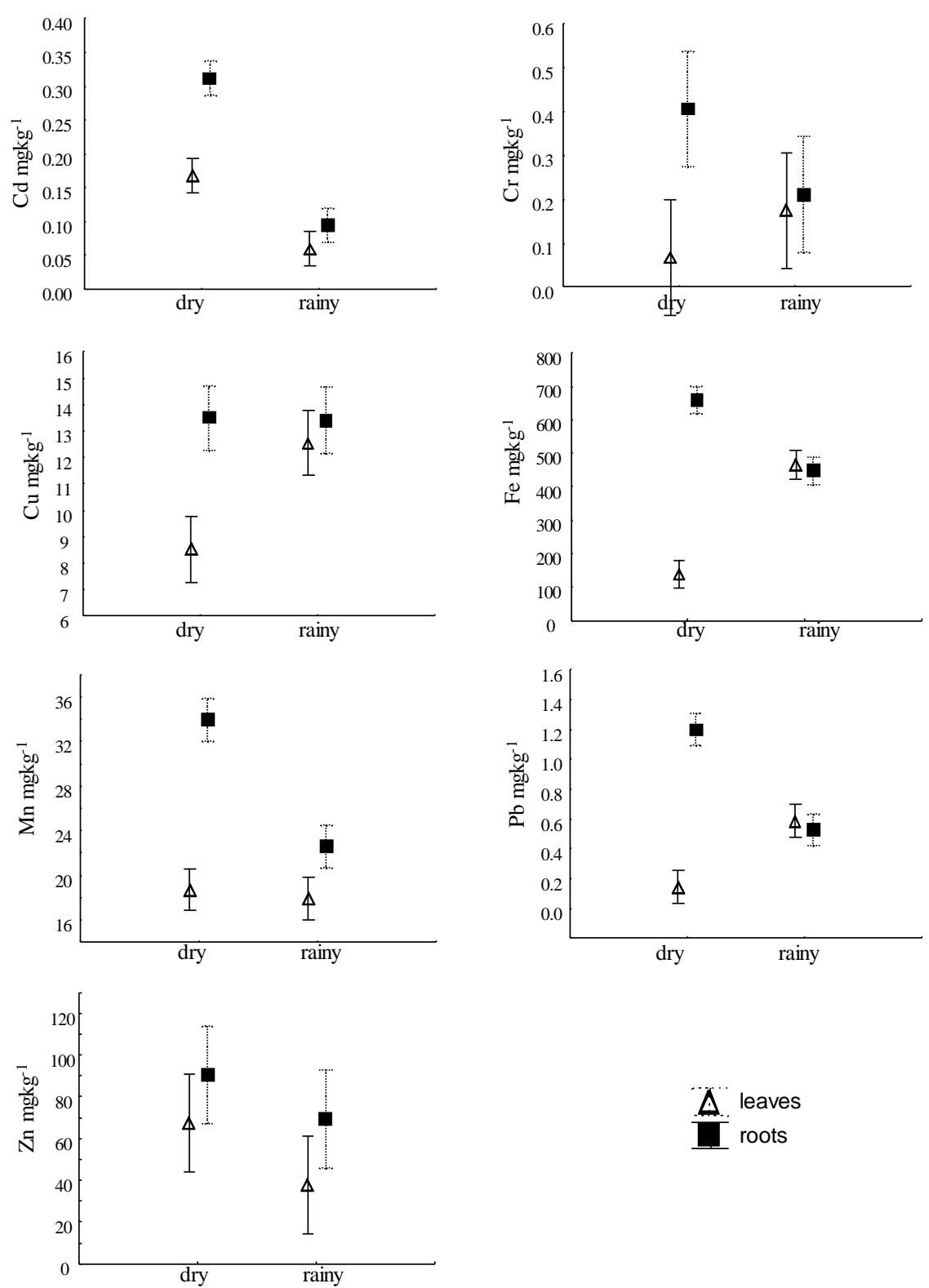

Figure 2. Metal concentrations in roots and leaves of lettuce (Lactuca sativa L.) in two seasons (Vertical bars: 0.95 confidence intervals).

There was no correlation between the total metal concentration in the soil and that of plants (leaves and roots), neither was between the labile metal fraction in the soil and the total concentration in plants. Similar results were reported by other authors [26] [33] [68] and these may be the effect of ion competition, which in turn affects the uptake rate of free ions [16] [69].

\subsection{Soil-Plant Relationships: Transfer and Translocation Factors}

In the context of food security, it is necessary to estimate the quantity of metals entering crops, particularly if an edible part is involved. It is also important to study the variables that enhance the flow of metals into the plant and their 
transfer to different organs; however, this is not an easy task because of the large number of factors involved. To evaluate the metal uptake from soils to lettuce and its translocation from roots to leaves (the edible part), we calculated the transfer factor (TrF, Figure 3) and translocation factor (TlF, Figure 4), for each metal.

Metal $\mathrm{TrF}$ in the dry season, behaved as follows: $\mathrm{Zn}>\mathrm{Cd}>\mathrm{Cu}>\mathrm{Mn}=\mathrm{Fe}=$ $\mathrm{Pb}=\mathrm{Cr}$, with the order of magnitude being almost the same for each metal. In contrast, in the rainy season, the $\operatorname{TrF}$ for $\mathrm{Cu}$ exceeded that for $\mathrm{Cd}$. During this

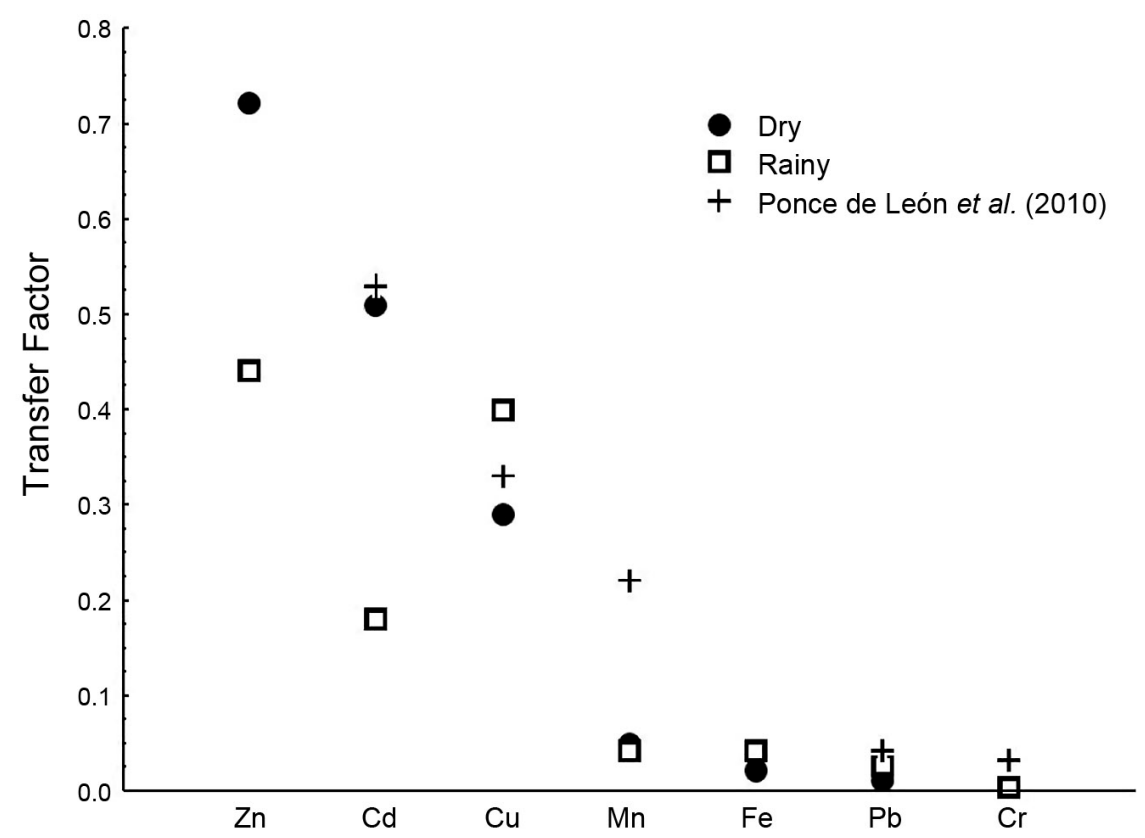

Figure 3. Transfer factors (dry weight) in lettuce in the dry and rainy seasons (2013) and those measured by Ponce de León et al. (2010) [33] in the same study area.

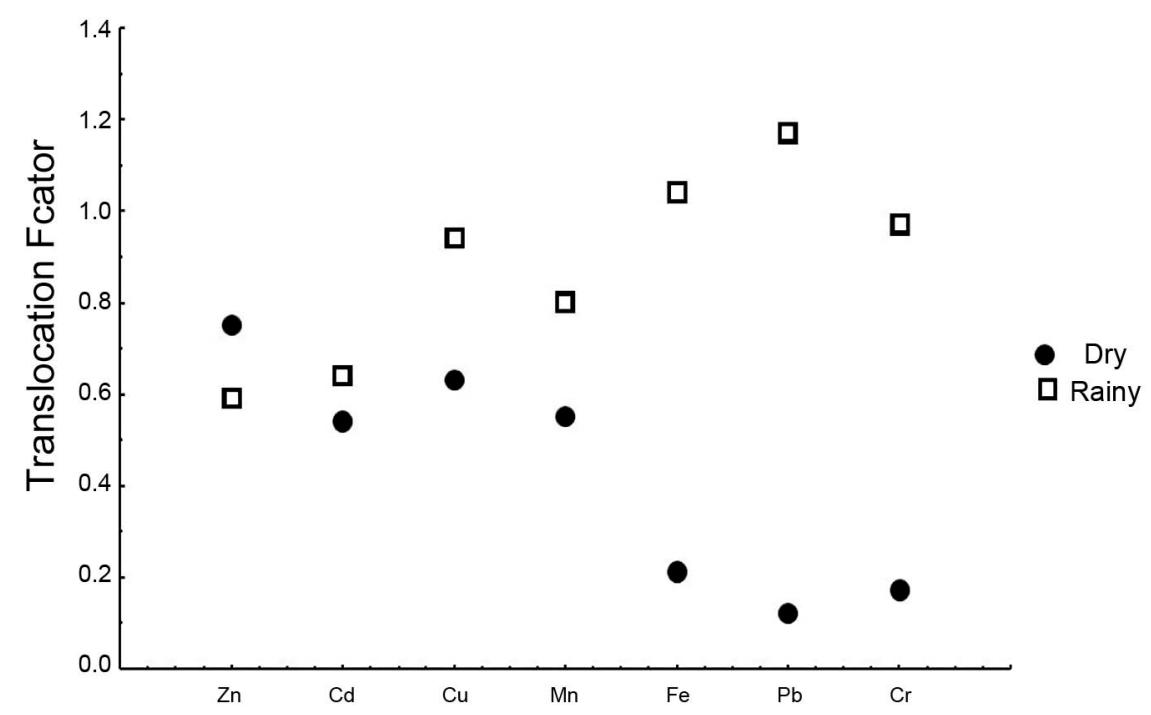

Figure 4. Metal translocation factor from roots to leaves in lettuce (Lactuca sativa L.) in the dry and rainy seasons. 
season, leaf \& root concentrations were higher for $\mathrm{Cu}, \mathrm{Fe}$ and $\mathrm{Pb}$, and the $\operatorname{TrF}$ indicates that $\mathrm{Cu}$ is absorbed to a greater extent with the rain regime; however, in the dry season the concentrations were higher for $\mathrm{Cd}, \mathrm{Zn}$ and $\mathrm{Mn}$, with the highest $\operatorname{TrF}$ for the first two (Table 4, Figure 3). It is known that the uptake rate generally increases with increasing concentration of free ions in pore water [16]. Our results show that this behavior is consistent for $\mathrm{Cu}$, but not for $\mathrm{Cd}$ and $\mathrm{Zn}$, which exhibit higher TrFs in the dry season.

The TrFs found are comparable to those measured by Ponce de León et al. (2010) [33] in the same studied area (samples collected in December and February). However, Uwah et al. (2011) [70] report higher TrF values for Cd (2.23 and 2.75), $\mathrm{Pb}(1.05,1.64)$, and $\mathrm{Fe}(0.71,0.79)$ and similar amounts for $\mathrm{Cu}(0.44,0.95)$ and $\mathrm{Zn}(0.55,0.47)$. Nevertheless, the agricultural region where the study was performed, although also irrigated with sewage water, is more arid (higher temperatures and less rainfall) than our study site and has sandy soils with low organic matter content.

Translocation is an important process in calculating trace metal concentrations in edible plant organs and it is element specific [71]. TlF values for all the metals measured, but $\mathrm{Zn}$, were higher in the rainy season than in the dry season. $\mathrm{Zn}, \mathrm{Cd}, \mathrm{Cu}$ and $\mathrm{Mn}$ had similar TlF values. However, the differences in TlFs found for $\mathrm{Fe}, \mathrm{Pb}$ and $\mathrm{Cr}$ were much greater in samples from the rainy season than those from the dry season. Although the $\operatorname{TrF}$ values for these three elements were very small and almost identical for both seasons, these are not reflected in the TlFs, which are completely different between seasons. There were higher concentrations of metals in the lettuce edible part in samples from the rainy season than those from the dry season, especially for $\mathrm{Fe}, \mathrm{Pb}$ and $\mathrm{Cr}$. The relative magnitudes of the TlFs differed between the two seasons: in the dry season, $\mathrm{Zn}>$ $\mathrm{Cu}>\mathrm{Mn}>\mathrm{Cd}>\mathrm{Fe}>\mathrm{Cr}>\mathrm{Pb}$; in the rainy season, $\mathrm{Pb}>\mathrm{Fe}>\mathrm{Cr}>\mathrm{Cu}>\mathrm{Mn}>$ $\mathrm{Cd}>\mathrm{Zn}$.

Plants suffer from osmotic stress during the dry season as a result of the high salt concentration in the wastewater used for irrigation, causing a decrease in soil osmotic potential and reducing the plant ability to absorb water [72]. In order to preserve water, the plant keeps its stomata closed, maintaining transpiration rates at their lowest and preventing water and nutrient movement into and within the plant. These processes can explain the low translocation factor for $\mathrm{Fe}$, $\mathrm{Pb}$ and $\mathrm{Cr}$ during the dry season and are reflected in the lettuce biomass (wet weight).

Lettuces harvested during the dry season weighed 40 percent less (wet weight) and were smaller than lettuces gathered in the rainy season, the latter incorporated more water and metals in their tissues; however, dry biomass was the same in both seasons. Although TlF was higher in the rainy season, only $\mathrm{Pb}$ and $\mathrm{Fe}$ values were slightly higher than 1 , so lettuce can be considered a metal accumulator plant in the rainy season for $\mathrm{Pb}$ and $\mathrm{Fe}$ [73]. Nonetheless, in the dry season the plant limits metal translocation and maintains most of them in the roots, 
acting as an excluder and keeping low levels in the aerial tissues.

$\mathrm{TlF}$ values are not constant for a given element and plant species. As mentioned before, metal speciation and uptake depend on a variety of factors: the plant genotype, the availability of the metal, the water content of the soil, and the temperature and humidity of the environment [74]; these may explain the differences in metal concentration values found between the dry and the rainy seasons.

Although it is important to know the physical and chemical characteristics of the pollutants, as well as the effects of changing environmental conditions on metal speciation and its accumulation in soils over time, this information is insufficient to know the likely uptake of the metal and the factors that promote its translocation into the plant [16]. The processes that regulate metal translocation are correlated with water transport and transpiration rates [75] [76]; therefore, in assessing the relationship between transpiration and metal solubility and movement, it is important to consider the species present at the time of absorption or translocation. In a study focused on Cd, Akhter and Macfie (2012) [76] reported that an increment in transpiration rates sometimes caused an increase in the accumulation of $\mathrm{Cd}$ in plants, including lettuce; however, the proportion of total metal transported to the leaves varied according to the plant species; this suggested that factors controlling the specific internal distribution of $\mathrm{Cd}$ compounds are more important than transpiration in the translocation of $\mathrm{Cd}$ to epigeous organs.

These differences can be attributed to the variation of plant responses to metals in soils [76], and they reinforce the argument that the uptake and accumulation of metals in the various organs of a plant depend on the correlation of many factors, such as plant species, developmental stage, edaphic characteristics, and soil organic matter [71] [77] [78] [79].

\section{Conclusions}

This study shows that lettuces grown in the chinampa soils of Xochimilco, Mexico City, accumulate metals but their uptake and transport differ between the two crop cycles analyzed, probably because of the difference in the quality of the water used for irrigation (wastewater and rainwater). More important, the metal concentration present in the plant tissues does not represent a threat to human health. During the dry season, the transfer of metals from the soil to the plant was higher than in the rainy season, but the root-to-leaf translocation was lower than in the rainy season.

To assess the local effects of metals in urban agriculture, it is necessary to perform site-specific studies. Moreover, it is important to gather information on the differences among the four lettuce harvests produced annually in these chinampas. It is critical to consider metal variability and availability in order to design sampling strategies which allow us to estimate long-term changes or to compare results among different studies. 


\section{Acknowledgements}

Funding for this research was provided by National Autonomous University of Mexico under grant number DGAPA-PAPIIT/IN104614.

\section{Conflicts of Interest}

The authors declare no conflicts of interest regarding the publication of this paper.

\section{References}

[1] Eriksen-Hamel, N. and Danso, G. (2010) Agronomic Considerations for Urban Agriculture in Southern Cities. International Journal of Agricultural Sustainability, 8, 86-89. https://doi.org/10.3763/ijas.2009.0452

[2] Khan, S., Farooq, R., Shahbaz, S., Khan, M.A. and Sadique, M. (2009) Health Risk Assessment of Heavy Metals for Population via Consumption of Vegetables. World Applied Science Journal, 6, 1602-1606.

[3] Nabulo, G., Black, C.R. and Young, S.D. (2011) Trace Metal Uptake by Tropical Vegetables Grown on Soil Ammended with Urban Sewage Sludge. Environmental Pollution, 159, 368-376. https://doi.org/10.1016/j.envpol.2010.11.007

[4] Reed, S.C., Crites, R.W. and Middlebrooks, E.J. (1995) Natural Systems for Waste Management and Treatment. McGraw-Hill, New York.

[5] Hamilton, A.J., Stagnitti, F., Xiong, X., Kreidl, S.L., Benke, K.K. and Maher, P. (2007) Wastewater Irrigation: The State of Play. Vadose Zone Journal, 6, 823-840. https://doi.org/10.2136/vzj2007.0026

[6] Wuana, R.A. and Okieimen, F.E. (2011) Heavy Metals in Contaminated Soils: A Review of Sources, Chemistry, Risks and Best Available Strategies for Remediation. International Scholarly Research Notices, 2011, Article ID: 402647. https://doi.org/10.5402/2011/402647

[7] Gharbi, L.T., Merdy, P. and Lucas, Y. (2010) Effects of Long-Term Irrigation with Treated Wastewater. Applied Geochemistry, 25, 1711-1721. https://doi.org/10.1016/j.apgeochem.2010.09.002

[8] Chary, N.S., Kamala, C.T. and Samuel Suman Raj, D. (2008) Assessing Risk of Heavy Metals from Consuming Food Grown on Sewage Irrigated Soils and Food Chain Transfer. Ecotoxicology and Environmental Safety, 69, 513-524. https://doi.org/10.1016/j.ecoenv.2007.04.013

[9] Balkhair, K.S. and Ashraf, M.A. (2016) Field Accumulation Risks of Heavy Metals in Soil and Vegetable Crop Irrigated with Sewage Water in Western Region of Saudi Arabia. Saudi Journal of Biological Sciences, 23, S32-S44. https://doi.org/10.1016/j.sjbs.2015.09.023

[10] Scott, C.A., Faruqui, N.I. and Raschid-Salli, I. (2004) Wastewater Use in Irrigated Agriculture Confronting the Livelihood and Environmental Realities. CABI Publishing, Colombo. https://doi.org/10.1079/9780851998237.0000

[11] Kabata-Pendias, A. (2004) Soil Plant Transfer of Trace Elements: An Environmental Issue. Geoderma, 122, 143-149. https://doi.org/10.1016/j.geoderma.2004.01.004

[12] Blume, H.P. and Brümmer, G. (1991) Prediction of Heavy Metal Behavior in Soil by Means of Simple Field Test. Ecotoxicology and Environmental Safety, 22, 164-174. https://doi.org/10.1016/0147-6513(91)90056-U

[13] Litz, N. (2004) Grundlagen zur Bewertung von flächenhaften Einträgen in Böden im 
Hinblick auf die Grundwasserbelastung. In: Litz, N., Wilcke, W. und Wilke, B.M., Eds., Boden gefährdende Stoffe, Wiley-VCH, Hoboken, Vol. III, 1-24.

[14] Violante, A., Cozzolino, V., Perelomov, L., Caporale, A.G. and Pigna, M. (2010) Mobility and Bioavailability of Heavy Metals and Metalloids in Soil Environments. Journal of Soil Science and Plant Nutrition, 10, 268-292. https://doi.org/10.4067/S0718-95162010000100005

[15] Villen-Guzmán, M., Paz-García, J.M., Amaya-Santos, G., Rodríguez-Maroto, J.M., Vereda-Alonso, C. and Gómez-Lahoz (2015) Effects of the Buffering Capacity of the Soil on the Mobilization of Heavy Metals. Equilibrium and Kinetics. Chemosphere, 131, 78-84. https://doi.org/10.1016/j.chemosphere.2015.02.034

[16] McLaughlin, M.J., Smolders, E., Degryse, F. and Rietra, R. (2011) Uptake of Metals from Soil into Vegetables. In: Swartjes, F.A., Ed., Dealing with Contaminated Sites: From Theory towards Practical Application, Springer Science + Business Media, Berlin, 325-367. https://doi.org/10.1007/978-90-481-9757-6 8

[17] Chojnacka, K., Chojnacki, A., Górecka, H. and Górecki, H. (2005) Bioavailability of Heavy Metals from Polluted Soils to Plants. Science of the Total Environment, 337, 175-182. https://doi.org/10.1016/j.scitotenv.2004.06.009

[18] Hough, R.L., Breward, N., Young, S.D., Crout, N.M.J., Tye, A.M., Moir, A.M. and Thornton, I. (2004) Assessing Potential Risk of Heavy Metal Exposure from Consumption of Home-Produced Vegetables by Urban Populations. Environmental Health Perspectives, 112, 215-221. https://doi.org/10.1289/ehp.5589

[19] Nabulo, G., Black, C.R., Craigon, J. and Young, S.D. (2012) Does Consumption of Leafy Vegetables Grown in Peri-Urban Agriculture Pose a Risk to Human Health? Environmental Pollution, 162, 389-398. https://doi.org/10.1016/j.envpol.2011.11.040

[20] Warming, M., Hansen, M.G., Holm, P.E., Magid, J., Hansen, T.H. and Trapp, S. (2015) Does Intake of Trace Elements through Urban Gardening in Copenhagen Pose a Risk to Human Health? Environmental Pollution, 202, 17-23. https://doi.org/10.1016/j.envpol.2015.03.011

[21] Chang, Y.T., Hseu, Z.Y. and Zehetner, F. (2014) Evaluation of Phytoavailability of Heavy Metals to Chinese Cabbage (Brassica chinensis L.) in Rural Soils. The Scientific World Journal, 2014, Article ID: 309396. https://doi.org/10.1155/2014/309396

[22] Ferreira, P., Lourenzi, C., Tiecher, T., Tiecher, T., Ricachenevsky, F., Brunetto, G., Giachini, A. and Soares, C. (2018) Physiological, Biochemical Changes, and Phytotoxicity Remediation in Agricultural Plant Species Cultivated in Soils Contaminated with Copper and Zinc, In: Hasanuzzaman, M., Nahar, K. and Fujita, M. Eds., Plants under Metal and Metalloid Stress. Responses Tolerance and Remediation, Springer Nature Singapore, Singapore, 29-76. https://doi.org/10.1007/978-981-13-2242-6 2

[23] Wuest, S.B. (2015) Seasonal Variation in Soil Bulk Density, Organic Nitrogen, Available Phosphorus, and pH. Soil Science Society of America Journal, 79, 1188-1197. https://doi.org/10.2136/sssaj2015.02.0066

[24] Murray, H., Pinchin, T.A. and Macfie, S.M. (2011) Compost Application Affects Metal Uptake in Plants Grown in Urban Garden Soils and Potential Human Health Risk. Journal of Soils and Sediments, 11, 815-829. https://doi.org/10.1007/s11368-011-0359-y

[25] Wuest, S.B. (2014) Seasonal Variation in Soil Organic Carbon. Soil Science Society of America Journal, 78, 1442-1447. https://doi.org/10.2136/sssaj2013.10.0447

[26] Mirecki, N., Agič, R., Šunić, L., Milenković, L. and Ilić, Z.N. (2015) Transfer Factor as Indicator of Heavy Metals Content in Plants. Fresenius Environmental Bulletin, 


\section{4, 4212-4219.}

[27] Organización de las Naciones Unidas para la Alimentación y la Agricultura (FAO) (2019) Chinampas de la Ciudad de México producen más de 19000 toneladas de alimentos. FAO en México, 23/12/2019.

http://www.fao.org/mexico/noticias/detail-events/es/c/1256562

[28] Outerbridge, T. (1987) The Disappearing Chinampas of Xochimilco. The Ecologist, 17, 76-83.

[29] Ramos-Bello, R., García-Calderón, N.E., Ortega-Escobar, H.M. and Krasilnikov, P. (2011) Artificial Chinampas Soils of Mexico City: Their Properties and Salinization Hazards. Spanish Journal of Soil Science, 1, 70-85.

[30] Quiñónez, C. (2005) Chinampas y Chinamperos: Los Horticultores de San Juan Tezompa, México. PhD Dissertation, Universidad Iberoamericana, México.

[31] Alatriste Guzmán, O. (2005) Xochimilco: Aspectos Históricos. Boletín. CELE- UNAM, 7, 119-139.

[32] López-López, E., Sedeño-Díaz, J., Ortiz, O.E., Rosas, C.M. and Abeja, P.O. (2010) Health Condition Assessment in Lake Xochimilco (Mexico). Romanian Journal of Biology Zoology, 55, 69-80.

[33] Ponce de León, C., Sommer, I., Cram, S., Murguía, F., Hernández, M. and Vanegas, C. (2010) Metal Uptake in Peri-Urban Lactuca sativa Cultivated Area. Journal of Environmental Science and Health, Part A, 45, 111-120. https://doi.org/10.1080/10934520903389275

[34] Vega, R.S. (2010) Determinación y Cuantificación de Algunos Metales Pesados en Suelo-Agua-Planta en un Área de la Zona Lacustre de Xochimilco-Mixquic, D.F. PhD Dissertation, Universidad Nacional Autónoma de México.

[35] Izazola, H. (2000) Water and Sustainability in Mexico City. Water and Development, II. UNESCO-EOLSS.

http://www.eolss.net/sample-chapters/c07/e2-24m-04-03.pdf

[36] García, E. (2004) Modificaciones al Sistema de Clasificación Climática de Köppen. Serie Libros Instituto de Geografía, 6, UNAM.

[37] Espinoza-Garcia, A.C. and Mazari-Hiriart, M. (2006) Atlas de Culturas del Agua en América Latina y El Caribe. Pueblos Indígenas de México y Agua: Xochimilcas México. Instituto de Ecología, UNAM, 1-30.

[38] Secretaría de Medio Ambiente y Recursos Naturales (SEMARNAT) (2002) Norma Oficial Mexicana NOM-021-RECNAT-2000, Que establece las especificaciones de fertilidad, salinidad y clasificación de suelos. Estudios, muestreo y análisis. SEMARNAT. http://diariooficial.gob.mx/nota detalle.php?codigo=717582\&fecha $=31 / 12 / 2002$

[39] Rhoades, J.D. (1996) Salinity: Electrical Conductivity and Total Dissolved Solids. In: Sparks, D.L., Page, A.L., Helmke, P.A. and Loeppert, R.H., Eds., SSSA Book Series, Methods of Soil Analysis, Part 3-Chemical Methods, SSSA, Madison, 417-435. https://doi.org/10.2136/sssabookser5.3.c14

[40] Bouyoucos, G.J. (1962) Hydrometer Method Improved for Making Particle Size Analysis of Soils. Agronomy Journal, 54, 464-465. https://doi.org/10.2134/agronj1962.00021962005400050028x

[41] Blake, G.R. and Hartge, K.H. (1986) Bulk Density. In: Klute, A., Ed., Methods of Soil Analysis, Part 1-Physical and Mineralogical Methods, 2nd Edition, Agronomy Monograph 9, American Society of Agronomy-Soil Science Society of America, Madison, 363-382. https://doi.org/10.2136/sssabookser5.1.2ed.c13

[42] U.S. Environmental Protection Agency (1996) Method 3052. Microwave Assisted 
Digestion of Siliceous and Organically Based Matrices. In: U.S. EPA, Ed., Test $\mathrm{Me}$ thods for Evaluating Solid Wastes. Physicall Chemical Methods, EPA SW-846, Third Edition, Chap. 3 (Inorganic Analytes), U.S. EPA, Washington DC. http://www.epa.gov/epaoswer/hazwaste/test/pdfs/3052

[43] Tipping, E. (1994) Wham: A Chemical-Equilibrium Model and Computer Code for Waters, Sediments, and Soils Incorporating: A Discrete Site Electrostatic Model of Ion-Binding by Humic Substances. Computers \& Geosciences, 2, 973-1023. https://doi.org/10.1016/0098-3004(94)90038-8

[44] Rangnekar, S.S., Sahu, S.K., Pandit, G.G. and Gaikwad, V.B. (2013) Accumulation and Translocation of Nickel and Cobalt in Nutritionally Important Indian Vegetables Grown in Artificially Contaminated Soil of Mumbai, India. Research Journal of Agricultural and Forest Sciences, 1, 15-21.

[45] Bu-Olayan, A.H. and Thomas, B.V. (2009) Translocation and Bioaccumulation of Trace Metals in Desert Plants of Kuwait Governorates. Research Journal of Environmental Sciences, 3, 581-587. https://doi.org/10.3923/rjes.2009.581.587

[46] Radulescu, C., Stihi, C., Popescu, I.V., Dulama, I.D., Chelarescu, E.D. and Chilian, A. (2013) Heavy Metal Accumulation and Translocation in Different Parts of Brassica oleracea L. Romanian Journal of Physics, 58, 137-1354.

[47] Zar, J.H. (2010) Biostatistical Analysis. Prentice Hall, Upper Saddle River.

[48] Sacco, D., Cremon, C., Zavattaro, L. and Grignani, C. (2012) Seasonal Variation of Soil Physical Properties under Different Water Managements in Irrigated Rice. Soil and Tillage Research, 118, 22-31. https://doi.org/10.1016/j.still.2011.10.011

[49] Koranda, M., Kaiser, C., Fuchslueger, L., Kitzler, B., Sesitsch, A., Zechmeister Boltenstern, S. and Richter, A. (2013) Seasonal Variation in Functional Properties of Microbial Communities in Beech Forest Soil. Soil Biology and Biochemistry, 60, 95-104. https://doi.org/10.1016/j.soilbio.2013.01.025

[50] Mohammad, M. and Mazahreh, N. (2003) Changes in Soil Fertility Parameters in Response to Irrigation of Forage Crops with Secondary Treated Wastewater. Communications in Soil Science and Plant Analysis, 34, 1281-1294. https://doi.org/10.1081/CSS-120020444

[51] Pacheco de Oliveira, P.C., Gloaguen, T.V., Bruschi Gonçalves, R.A., Lima Santos, D. and Fonseca, C. (2016) Soil Chemistry after Irrigation with Treated Wastewater in Semiarid Climate. Revista Brasileira de Ciência do Solo, 40, e0140664. https://doi.org/10.1590/18069657rbcs20140664

[52] Bolan, N., Kunhikrishnanc, A., Thangarajan, R., Kumpiene, J., Park, J., Makino, T., Kirkham, M.B. and Scheckel, K. (2014) Remediation of Heavy Metaloids Contaminated Soils to Mobilize or to Inmobilize? Journal of Hazardous Materials, 266, 141-166. https://doi.org/10.1016/j.jhazmat.2013.12.018

[53] Bolan, N.S., Adriano, D.C., Kunhikrishnan, A., James, T., McDowell, R. and Senesi, N. (2011) Dissolved Organic Matter: Biogeochemistry, Dynamics, and Environmental Significance in Soils. Advances in Agronomy, 110, 3-75. https://doi.org/10.1016/B978-0-12-385531-2.00001-3

[54] Reyes Ortigoza, A.L. and García Calderón, N.E. (2004) Evolución de las Fracciones Húmicas de Suelos en la Zona Chinampera de la Ciudad de México. Terra Latinomericana, 22, 289-298.

[55] Schindler, D.W., Bayley, S.E., Curtis, P.J., Parker, B.R., Stainton, M.P. and Kelly, C.A. (1992) Natural and Man-Caused Factors Affecting the Abundance and Cycling of Dissolved Organic Substances in Precambrian Shield Lakes. Hydrobiologia, 229, 1-21. https://doi.org/10.1007/BF00006987 
[56] Herre, A., Siebe, C. and Kaupenjohann (2004) Effect of Irrigation Water Quality on Organic Matter, Cd and Cu Mobility in Soils of Central Mexico. Water Science and Technology, 50, 277-284. https://doi.org/10.2166/wst.2004.0142

[57] Xiao, H. and Zheng, X. (2000) Effects of Soil Warming on Some Soil Chemical Properties. Soil and Environmental Sciences, 9, 316-321.

[58] Canadian Council of Ministers of the Environment (CCME) (2007) Canadian Soil Quality Guidelines (CSQG) for the Protection of Environmental and Human Health: Summary Tables. Updated September, 2007. In: Canadian Environmental Quality Guidelines, 1999, Canadian Council of Ministers of the Environment (CCME), Winnipeg, 1-9.

[59] Carranza, B.H. (2016) Absorción de Metales por Lechuga (Lactuca sativa) Cultivada en Chinampas de San Gregorio Atlapulco, Xochimilco. MSc Dissertation, Universidad Nacional Autónoma de México.

[60] Amlinger, F., Pollak, M. and Favoino, E. (2004) Heavy Metals and Organic Compounds from Wastes Used as Organic Fertilisers. ENV.A.2./ETU/2001/0024, Final Report. http://ec.europa.eu/environment/waste/compost/pdf/hm finalreport.pdf

[61] Solís, C., Sandoval, J., Pérez-Vega, H. and Mazari-Hiriart, M. (2006) Irrigation Water Quality in Southern Mexico City Based on Bacterial and Heavy Metal Analyses. Nuclear Instruments and Methods in Physics Research B, 249, 592-595. https://doi.org/10.1016/j.nimb.2006.03.062

[62] Zambrano, L., Contreras, Mazari-Hiriart, V.M. and Zarco-Arista, A.E. (2009) Spatial Heterogeneity of Water Quality in a Highly Degraded Tropical Freshwater Ecosystem. Environmental Management, 43, 249-263.

https://doi.org/10.1007/s00267-008-9216-1

[63] Emberson, L.D., Ashmore, M.R., Murray, F., Kuylenstierna, J.C.I., Percy, K.E., Izuta, T., Zheng, Y., Shimizu, H., Sheu, B.H., Liu, C.P., Agrawal, M., Wahid, A., Abdel-Latif, N.M., van Tienhoven, A.M., de Bauer, L.I. and Domingos, M. (2001) Impacts of Air Pollutants on Vegetation in Developing Countries. Water Air Soil Pollut., 130, 107-118.

[64] Blum, W.E.H., Horak, O., Mentler, A. and Puschenreiter, M. (2012) Trace Elements. In: Sabljic, A., Ed., Environmental and Ecological Chemistry, Vol. 2, UNESCO-EOLSS, Oxford, 156-164.

http://www.eolss.net/sample-chapters/c06/e6-13-03-04.pdf

[65] Amery, F., Degryse, F., Cheyns, K., De Troyer, I., Mertens, J., Merck, R. and Smolders, E. (2008) The UV-Absorbance of Dissolved Organic Matter Predicts the Fivefold Variation in Its Affinity for Mobilizing $\mathrm{Cu}$ in an Agricultural Soil Horizon. European Journal of Soil Science, 59, 1087-1095. https://doi.org/10.1111/j.1365-2389.2008.01078.x

[66] Bongiovanni, M.D. and Lobartini, J.C. (2009) Efecto de Sustancias Orgánicas Solubles del Suelo Sobre la Absorción de Hierro en Plántulas de Girasol. CI. Suelo, 27, 171-176.

[67] Weng, L.P., Temminghoff, E.J.M., Lofts, S., Tipping, E. and van Riemsdijk, W.H. (2002) Complexation with Dissolved Organic Matter and Solubility Control of Heavy Metals in a Sandy Soil. Environmental Science \& Technology, 36, 4804-4810. https://doi.org/10.1021/es0200084

[68] Demirezen, D. and Aksoy, A. (2006) Heavy Metal Levels in Vegetables in Turkey Are within Safe Limits for $\mathrm{Cu}, \mathrm{Zn}, \mathrm{Ni}$ and Exceeded for $\mathrm{Cd}$ and $\mathrm{Pb}$. Journal of Food Quality, 29, 252-265. https://doi.org/10.1111/j.1745-4557.2006.00072.x

[69] Nolan, A.L., Lombi, E. and McLaughlin, M.J. (2003) Metal Bioaccumulation and 
Toxicity in Soils: Why Bother with Speciation? Australian Journal of Chemistry, 56, 77-91. https://doi.org/10.1071/CH02226

[70] Uwah, E.I., Ndahi, N.P., Abdulrahman, F.I. and Ogugbuaja, V.O. (2011) Heavy Metal Levels in Spinach (Amaranthus caudatus) and Lettuce (Lactuca sativa) Grown in Maiduguri, Nigeria. Journal of Environmental Chemistry and Ecotoxicology, 3, 264-271.

[71] Guo, Y.T. and Marschner, H. (1995) Uptake, Distribution, and Binding of Cadmium and Nickel in Different Plant Species. Journal of Plant Nutrition, 18, 2691-2706. https://doi.org/10.1080/01904169509365094

[72] Munns, R. (2002) Comparative Physiology of Salt and Water Stress. Plant, Cell \& Environment, 25, 239-250. https://doi.org/10.1046/j.0016-8025.2001.00808.x

[73] Ma, L.Q., Komar, K.M., Tu, C., Zhang, W., Cai, Y. and Kennelley, E.D. (2001). A Fern That Hyperaccumulates Arsenic. Nature, 409, 579-579. https://doi.org/10.1038/35054664

[74] Smical, A.I., Hotea, V., Oros, V., Juhasz, J. and Pop, E. (2008) Studies on Transfer and Bioaccumulation of Heavy Metals from Soil into Lettuce. Environmental Engineering and Management Journal, 7, 609-615.

https://doi.org/10.30638/eemj.2008.085

[75] Li, F.-L., Wen, S., Jin, Z.-F., Wu, H.-M. and Sheng. G.D. (2017) Excessive Uptake of Heavy Metals by Greenhouse Vegetables. Journal of Geochemical Exploration, 173, 76-84. https://doi.org/10.1016/j.gexplo.2016.12.002

[76] Akhter, F. and Macfie, S. (2012) Species-Specific Relationship between Transpiration and Cadmium Translocation in Lettuce, Barley and Radish. Journal of Plant Studies, 1, 2-13. http://ir.lib.uwo.ca/biologypub/36 https://doi.org/10.5539/jps.v1n1p2

[77] Hatch, D.J., Jones, L.H.P. and Burau, R.G. (1988) The Effect of pH on the Uptake of Cadmium by Four Plant Species Grown in Flowing Solution Culture. Plant and Soil, 105, 121-126. https://doi.org/10.1007/BF02371149

[78] Filipović-Trajković, R., Ilić, S.Z. and Šunić, L. (2012) The Potential of Different Plant Species for Heavy Metals Accumulation and Distribution. Journal of Food, Agriculture \& Environment, 10, 959-964.

[79] Lu, H., Yao, H., Shan, D., Jiang, Y., Zhang, A. and Yang, J. (2015) Heavy Metal Residues in Soil and Accumulation in Maize at Long-Term Wastewater Irrigation Area in Tongliao. Chinese Journal of Chemistry, 2015, Article ID: 628280.

https://doi.org/10.1155/2015/628280 